\title{
THE ATTITUDES TOWARDS WOMEN IN THE MARY PLAY AND THE ROARING GIRL
}

\author{
THE MARY PLAY VE THE ROARING GIRL'DE KADINLARA KARŞI TUTUM
}

\section{Yasemin ŞANAL*}

*Dr. Öğr. Üyesi Zonguldak Bülent Ecevit Üniversitesi, Yabanc1 Diller Yüksekokulu, Mütercim-Tercümanlık Bölümü, Zonguldak/Türkiye ORCID: 0000-0002-7574-8203

\section{Yazısma Adresi:}

Yasemin Şanal

E posta:yaseminunal@yahoo.com.tr

Gönderim Tarihi: 20 Mart 2021

Kabul Tarihi: 08 Mayıs 2021

\begin{abstract}
Women's marital status has always been a controversial issue for the public opinion over the centuries because a woman's gender almost always brings her certain limitations and expectations. The gender norms imposed on people and the stereotyped gender roles usually determine the attitude towards women in many countries. This study aims to examine two dramatic works "The Mary Play" and "The Roaring Girl" which show the attitude towards women both in the Medieval and in the Early Modern England. The attitude towards women in terms of gender norms and the concept of marriage are analysed in both plays, and it is seen that the accepted gender roles in these two plays are so similar to each other that the femininity and the marital status of both female characters are at the center of public concern. Yet, there is a certain attitude in both plays contradictory to the patriarchal mindset of femininity, marriage and motherhood, which can be regarded as a pioneer of feminism that will emerge a few centuries later.
\end{abstract}

Keywords: Gender Roles, Woman, Protofeminism, The Mary Play, The Roaring Girl

\section{$\ddot{O Z Z}$}

Kadınların evli olup olmamalar yüzylllardır toplum içinde tartışma yaratan bir konu olagelmiştir, zira bir kadının cinsiyeti ona neredeyse her zaman belli başlı kisitlamalar ve beklentiler getirir. Birçok ülkede kadınlara karşı olan tutumu insanlara dayatılan cinsiyet normları ve kalpplaşmış cinsiyet rolleri belirlemektedir. Bu çalışmada, Ingiltere'de hem Ortaçağ hem de Erken Modern Dönem'de kadınlara karşı tutumu yansitan "The Mary Play" ve "The Roaring Girl" isimli iki oyun incelenecektir. Bu oyunlarda kadinlara karşı tutum, cinsiyet normları ve evlilik kavramı bakımından bir incelemeye tabi tutulmuş ve görülmüştür ki her iki oyunda da toplumca normal kabul edilen cinsiyet rolleri birbirine çok benzemektedir ve her iki kadın karakterin kadın olmaları dolaylslyla evli olup olmamaları yaşadlkları toplum için birer merak ve endişe konusudur. Nitekim, her iki oyunda da kadınlık, evlilik ve annelik ile alakalı ataerkil düşünce yapısina ters düssen bir tutum görmek mümkündür, ki bu da birkaç yüzyıl sonra ortaya çıkacak olan feminizm için öncü bir tutum olarak kabul edilebilir.

Anahtar Kelimeler: Cinsiyet Rolleri, Kadın, Protofeminizm, The Mary Play, The Roaring Girl

Atıf için (How to cite): Şanal Y. The Attitudes Towards Women in The Mary Play and The Roaring Girl. Atatürk Üniversitesi Kadın Araştırmaları Dergisi, 2021; 3 (1): 1-15 


\section{INTRODUCTION}

Women have always been at the center of discussions throughout the history of humanity. They have been regarded as sinful or weak in creation, and classified as virgin, maiden, wife, mother, widow, barren, spinster, wench, whore, witch, and so on with regards to their marital status. For many centuries, even the social rights given to women were shaped according to their marital status. Most importantly, women were treated as the lower gender and were neglected as a human being in most societies where men were dominant and women were oppressed, which is referred to as patriarchy. As a matter of fact, the result of patriarchy is usually the inequality and suppression of women. The prolonged oppression of women raised many voices over centuries, and caused the longstanding debate about gender inequality which eventually gave way to a new philosophy called 'feminism', which can simply be defined as "the belief in social, economic, and political equality of the sexes"

(https://www.britannica.com/topic/feminis $\underline{\mathrm{m}}$ ). Probably the longest movement in history, in consequence of the studies on human rights opposing patriarchy, feminism first emerged in France at the end of the 1700s with the effect of the French Revolution, spread all over the world from there, and continues to exist as a philosophy that is still valid today.

In fact, long before the French Revolution, gender had always been a central focus, and femininity a subject matter for many people. "Although the term "feminism" has a history in English linked with women's activism from the late nineteenth century to the present, it is useful to distinguish feminist ideas or beliefs from feminist political movements, for even in periods where there has been no significant political activism around women's subordination, individuals have been concerned with and theorized about justice for women" (https://plato.stanford.edu/entries/feministphilosophy/). Indeed, it is possible to come across the pioneers of feminism, namely the protofeminists, in ancient civilizations that lived thousands of years ago. Therefore, as İplikçi Özden (2016) suggests, feminism should not be considered as a contemporary approach or dating back to only a few centuries ago, because traces of feminism can be seen even in the ancient Greek literature. For instance, powerful female characters can be found in the works of Sappho and Aristophanes, and especially Aristophanes's Lysistrata can be considered as a literary work that forms the basis of the development process of feminism. Plato, also, discusses the gender discrimination and the situation of woman in The Republic (c. 375 BC). In Book V, while comparing and contrasting the attitude towards women among the humanbeings with the attitude towards the females among the dogs, he points out that it is only peculiar to the mankind to differentiate the females from the males in the social sphere. Moreover, he argues that women and men should be treated equally (Plato, 1937).

Actually, the inequality between genders was a fact which existed much earlier than the Ancient Greeks. In the ancient Mesopotamia, as Bottéro (2001) points out, the wives were entirely under the authority of their husbands, and social constraints were not kind to them. The head of the household and the supreme authority both in the government and in 
the home was the husband whereas women were regarded at all levels as inferior to men and treated as such. Yet, the first known female poet in history, who lived in the $23^{\text {rd }}$ century BC, Akkadian highpriestess Enheduanna's position of great power and influence on the culture of her time makes her a distintive woman who attracts the attention of the feminists even today.

Traces of feminism could be found in the Medieval Age too, especially in the works of Geoffrey Chaucer and Christine de Pisan. Chaucer's Wife of Bath (c. 14051410) and Pisan's The Book of the City of Ladies (1405) both portray experienced and powerful women which makes them the forerunners of the feminist philosophy in the Medieval Era. Next to Pisan, Laura Cereta could be regarded as one the first feminist philosophers, or protofeminists, who lived long before the emergence of feminism as a distinctive philosophy. Cereta's writing in the form of letters, published in 1488 as a series of manuscripts, discusses women's education and marriage in which she fervently protests those who believe that women are not able to attain eloquence in any subject through education, and that a learned woman is scarcely seen in the world (Cereta, 1997).

The Early Modern Era, particularly the $17^{\text {th }}$ century, witnessed many female writers discussing the situation of their own gender, who objected the abuse of married woman, defended the worth of women and equality between sexes particularly in terms of education, such as Jane Anger, Moderata Fonte, Margaret Cavendish, Margaret Fell, Hannah Woolley, Bathsua Makin, and Mary Astell. The first English woman to earn a living by a writing career in the 17 th century,
Aphra Behn, too, supported and contributed to women's freedom to think and to express their thoughts and thus to feminism. For instance, her The Forc'd Marriage (1670), The Rover (1677), The Roundheads (1680), and The City Heiress (1682) deal with gender inequality, and the male-dominated institution of marriages, while ridiculing the male authorities and annihilating the streotypical gender roles.

As for the religious point of view; in the Pauline Epistles, thirteen books of the New Testament, it seen that St. Paul, a Christian apostle who spread the teachings of Jesus Christ in the $1^{\text {st }}$ century, argues that Adam was not the one deceived; it was the woman who was deceived and became a sinner, and claims that a woman can only be saved through childbearing if they continue in faith, love and holiness with

propriety (https://www.biblegateway.com/passage/?s earch=1\%20Timothy+2\&version=NIV).

Therefore, women should get married since they are in need of shelter and protection by men in order to be prevented from making mistakes or committing sins. They should also be loyal to their husbands in full submission in order to reach salvation and to be protected from damnation. Since the Pauline Epistles, or the Letters of Paul, are among the earliest extant Christian texts, they provide us to see the general attitude towards women in the $1^{\text {st }}$ century world, which continued to be valid even after centuries.

The dominant view or general attitude regarding female members of the society was that they were weaker than the males both physically and emotionally, and most importantly, they were potential sinners. Therefore, young girls were expected to make a proper marriage in order to find shelter, and since women 
were believed to be destined to marry and become mothers, the aim of a young girl's life was beyond doubt marriage. Besides, as Alkan (2018) points out, "women were not offered any option other than marriage, and were not given any role in the society other than being a wife and mother". The majority of the society thought that women should always stay behind men and continue their lives as assisstants to them, and if there was a woman who did not want to marry, she was regarded as strange in the eyes of the society. Furthermore, "single women were not permitted to live alone; instead, they were supposed to live with their male relatives or join the convent and become a nun. Child care was one the most important duties of women because motherhood was the most praiseworthy destination in a woman's life” (Şanal, 2018). As Gerda Lerner (1987) suggests, "the traditionalist explanation of female subordination focuses on woman's reproductive capacity and sees in motherhood woman's chief goal in life, by implication defining as defiant women who do not become mothers".

Female subordination and male supremacy, of course, gave rise to many opposing views which contributed to the emergence of the feminist philosophy. The pioneering ideas that led to the birth of feminism, which may as well be called protofeminism, could also be seen in many literary works. Thus, in order to survey the attitudes toward the female gender from the Middle Ages to the Renaissance in England, The Mary Play (dated between 1450-1500) and The Roaring Girl (ca. 1610) could be examined since they are two basic sources which show both the medieval and the early modern societies and traditions along with the accepted gender norms. Both plays deal with female subordination and male supremacy in a critical way, which makes them representatives of protofeminism. Hence, analysing the attitude towards women in these two plays written before the appearance of feminism will help us to better understand the conditions of women that paved way for the formation and development feminist theory several centuries later.

The Mary Play And The Medieval Attitude Towards Women

Originally published in the N-Town (or the N.Town) Plays, the manuscript of the English mystery plays telling the Biblical history from the Creation to the Judgement Day, which consists of 42 plays, The Mary Play was staged as part of a cycle like the other English mystery plays such as York and Chester cycles. As for the location of the N-Town cycle, Prof. Peter Meredith (1997) states that the Middle English Dialect Survey has placed the main scribe of the N-Town manuscript in south central Norfolk. The Mary Play has survived since the late $15^{\text {th }}$ century which is a unique text that tells the story of Virgin Mary, and her parents. It deals with her early life, how she was born, grew up, and got married, and ends when Mary and her husband Joseph take their leave from Elizabeth and Zachary's house. Because it starts from the story of her parents Anne and Joachym, it also reveals a clearer idea about the public life of the time.

As it is seen in the play, Joachym and Anne, Virgin Mary's parents, were both barren. They were not allowed to make a sacrifice to God in the feast called Festum Encenniorum in Jerusalem by the priest, Ysakar, because neither of them was fruitful. Nevertheless, from the very 
beginning of the play Joachym seems to accept their being barren and he does not say any accusing words about or toward his wife Anne. Instead, he mentions her as 'blessed' and he prays God to have mercy on his wife:

Punish me, Lord, and spare my blessed wife Anne

Who sits and sorrows full sore in my absence.

There is no one may profit, but prayer in your presence.

With prayers, prostrate, before thy person I weep;

Have mind of our vow for your much magnificence,

And my most loving wife, Anne, Lord for thy mercy keep. (159 165)

Considering that they live in a patriarchal societ, and that there were not any medical treatments for this at that time, it is quite a fair and equal attitude of a husband toward his wife. The aim of the playwright seems to show that the real relationship between husband and wife should be like Anne and Joachym's marriage. Joachym and the rest of the society do not show a unilateral approach to their situation. Instead, Joachym blames himself for their barrenness as he leaves the city of Nazareth in sorrow and shame.

Anne, in the meantime, blames herself and prays God for his mercy. She is now left alone, so she can easily be harmed and offended by other people. During Joachym's absence an angel appears to Anne, and says that they will have a child who should be called Mary. After Joachym returns home, they share their happiness. However, it is not clear what Joachym actually thinks this time because he says:
Ah, gracious wife Anne, now fruitful shall you be!

For joy of this meeting, in my soul I weep. (239 - 240)

The first sentence is ambigious because it both gives the idea that Joachym says so as he thinks he is still barren but Anne is now fruitful, and also he might have thought Anne was responsible for their barrenness from the beginning and now she has become fruitful by God's mercy. But the first idea looks more correct because Anne will bear the baby without having an intercourse with her husband. The playwright, again, shows a fair attitude towards the wife rather than being one-sided.

Although they live in a maledominated society, in the play, the married couples do not seem to accept the husband as a leader rather than a protector for the wife in marriage. Both Joachym and Anne, Elizabeth and Zachary, and even Mary and Joseph have high respect for one another and they get on well with each other. Anne calls Joachym as "husbonde so hende"1 which means he is both her husband and a close friend. The play, indeed, portrays a marriage that is not male-dominated, at least ideally, with the aim of showing that the Virgin Mary came from such a family that shall be an example for the rest of the world.

The play also portrays the social norms of the time regarding marriage and reproduction. It is seen that marriage was considered to be a highly respected social institution as men and women were supposed to take part in the continuity of life by getting married. Besides, families

\footnotetext{
1 "Hende" is on Old English word which was commonly used by Geoffrey Chaucer, meaning both gentle, friendly, kind, gracious, and near, close, handy within the context it was used.
} 
bereft of a child were usually degraded by the rest of the society, they were even not allowed to make a sacrifice to God like Joachym and Anne. Nonetheless, virginity was regarded as the perfect status for both men and women, and it was highly respectable to have strong resistance to bodily temptations and stay as a maiden. For this reason, as it is seen in the play, when Mary is only three years old, her mother asks her whether she is going to be a pure maiden and also God's wife. Upon her agreement, Anne and Joachym take Mary to the temple to be raised as a maiden. Thus, Mary grows up in the temple with five maidens, but when she is only fourteen years old, the law commands her to get married, so Joseph is chosen by the bishop to marry her.

There is not any information in the play about the age that men should marry according to the law. So, the law might be only for females as Joseph, Mary's husband, is told to be an old man who actually wants to live and die a celibate in the play. Therefore it is clear that there were laws mostly for women about their marital status. The reason of this might be the supposed role of females, i.e. childbearing, insomuch that they had to get married after they became fertile. The bishop refers to this law when he talks about Mary's marriage, as well:

Listen, my lords, both high and low,

And tenderly take heed unto my saw.

Be obedient and benign your bishop to know,

For I am that lord that made this law.

With hearts so faithful, hearken now!
Your damsels to wedding, yea, look that ye draw,

That are past fourteen years, for that which ye owe.

The law of God biddeth this saw:

That at fourteen years of age,

Every damsel, whoso she be,

To the increase of more plenty,

Should be brought in good degree

Unto her spousage. (594 - 606)

Here, as the bishop states, according to the law young girls who reach fourteen years of age should be married in order for the reproduction of humanbeings. On the other hand, Joseph is worried that it is very strange for an old man like him to marry a young girl. But this marriage is actually perfect for both of them because Joseph is so old that he even cannot walk properly, and thus he will not be able to act like a real husband for Mary who wants to live as a maiden, and he can as well stay chaste for the rest of his life. Yet, he is also concerned about the public opinion of their marriage because of the age difference between them, and says:

Ah! Should I have her, ye lose my life.

Alas, dear God, should I now rave?

An old man may never thrive

With a young wife, so God me save.

Nay, nay, sir, let be!

Should I now in age begin to dote?

If I her chide she would clout my coat,

Blear my eye and pick out a mote,

And thus oftentimes it is seen. (849

- 857)

It is noteworthy here that he uses the word "have" instead of "marry" in the first sentence. Even the bishop uses the same word when he asks Joseph if he accepts Mary as his wife. This might mean 
that they see marriage as a kind of trade in which men take women under their control when they are tied with the bond of marriage. But Joseph cannot actualize this deed due to his old age, and instead he behaves as a kind and caring husband after he agrees to be "her warden and keeper". The play, here, depicts a different idea on marriage for the husband is seen as a caretaker for the wife. Joseph's attitude to his wife is clearly seen in this speech of him:

Mary wife and maid most gracious, Displease you not, I pray you, so long I have been.

I have hired for us a little pretty house

And right easily we may live therein. $(1030$ - 1033)

Her husband wants to keep Mary away from rumours and all other displeasures that could arise from the curiosity of the society. Therefore, he hires a small house where they may live in seclusion. It appears that the bishop shares the same concerns with Joseph as he says that there will be rumours about them due to the age difference between them. So he sends three maidens to watch over Mary. Her mother advises her to be an obedient and meek wife, and calls her "my dowtere 3yng"2 indicating that she knows her daughter is still so young to get married. Fourteen is a really young age to get married, yet they have to obey the law. Furthermore, the basic role of women in the society was considered to become a mother and the chief purpose of marriage was bearing and raising children. However, in the case of Mary and Joseph, it does not seem possible for them to have children.

\footnotetext{
${ }^{2}$ my daughter young ( the Mary Play, line 977)
}

Joseph himself is fully aware of this, and he tells his wife to keep herself clean when he goes to work in a different country. It is also notable that even Mary prays God to save her husband from shame, and she stays with her maidens who are there to make sure she keeps herself clean. When he is away, the angel Gabriel appears to Mary and tells her that she is going to bear the son of the Trinity, who shall be called Jesus. Again Mary is concerned about her maidenhood and the public opinion, as well. Yet, Gabriel tells her that her barren cousin Elizabeth's expecting a baby in her old age might be seen as a proof of Mary's prophesied pregnancy by the society:

And see, Elizabeth, your cousin there,

She hath conceived a son in her age $--$

This is the sixth month of her passage,

Of her that was called barren --

Nothing is impossible to God's usage. (1318 - 1322)

Gabriel informs Mary that it is the sixth month of her cousin's pregnancy, and she is going to have a son. She used to be infertile in her youth, yet it is God who makes everything possible. However, on Joseph's return, since Mary is ashamed and frightened of being seen by people, they go to Montana to visit Elizabeth and her husband Zachary in order to praise Elizabeth's miraculous pregnancy. They decide to stay there till the birth of Elizabeth's baby and help her during the last trimester of her pregnancy. The play ends as Mary and Joseph take their leave after the birth of Elizabeth's son, John.

Considering that The Mary Play shows the attitude towards the female sex and the role of women in society in the 
medieval times, the play seems to depict a non-patriarchal approach to the relationship between men and women, which could also be regarded as a protofeminist approach. Martti Nissinen draws the attention to a different aspect and states that women's role in reproduction was considered to be passive as a woman's body was seen as the soil for a seed only. Men had the active role in reproduction and gave the seed which contained the origin of life. But with the developments in medical sciences, the better understanding of women's body helped to change this opinion about women and their role in the continuity of life in relation with their status in the society (1998).

The Roaring Girl And The Early Modern Attitude Towards Women

The Mary Play gives us information about Jesus Christ's mother Virgin Mary, the most well-known female figure all over the world, and the society in which she was born and raised. The Roaring Girl, on the other hand, presents a completely different female figure that lived in the Early Modern London, which tells the story of a 'disorderly' woman named Moll Cutpurse. Like The Mary Play, it shows the customs and the public life of its time, as well.

First published in 1611, the play was co-written by Thomas Middleton and Thomas Dekker in the form of a city comedy (also called 'citizen comedy'), a popular genre of Jacobean drama, which satirically handles the life and manners of the London middle-class. The character of Moll is based on the real life story of a notorious pickpocket, Mary Frith, also known as Moll Frith or Moll Cutpurse, who used to dress up like a man. Her second nickname "the roaring girl" derives from "the roaring boy", a term used for young men who used to drink a lot and fight noisily on the streets. However, Moll, in Dekker and Middleton's play, differs from the real life person as she is actually decent and honest unlike the public opinion about her (https://www.historicuk.com/HistoryUK/HistoryofEngland/Moll -Frith/).

The play begins as Sebastian Wengrave plans to woo Moll Cutpurse to make his father allow his marriage to Mary Fitzallard supposing that if he pretends to be in love with another girl who is socially low and publicly known as a criminal, his father will think Mary is a better daughterin-law for him and eventually let them marry even though she does not have a large dowry. However, when Sir Alexander Wengrave overhears Sebastian wooing Moll, he calls it an 'improper' marriage and decides to pursue her in order to ruin her reputation. To his relief, Mary Fitzallard is the one whom Sebastian secretly marries. Sir Alexander forgives them at once and blesses the newly wed couple. At the end of the play, Sebastian's father asks for Moll's pardon and says that he will not judge anybody just according to the public opinion any more.

The attitude towards women differs from one woman to another depending on their social status in this play. Mary Fitzallard is respected by others because she is the daughter of Sir Guy Fitzallard while Moll is seen as a potential thief and a whore. The play does not give clear information about Moll's occupation, but it is obvious that she knows quite a lot about London and the underworld of the time. The text does not tell Moll's age either but she should be young enough for Sebastian to regard her considerable for marriage. Lord Noland also asks her when 
she will get married at the end of the play. So she should be in her early twenties which is the age of marriage for a woman in most societies at that time, and even today. Moll's cross-dressing and her attitude towards marriage were the two things which challenged the stereotypical female ideal of the time; hence both her femininity and her reputation were usually attacked by the patriarchal society. For example, Laxton, one of the gallants in the play who pursue women flirtatiously, courts Moll and thinks that she is morally loose because she dresses like a man, and regards her a prostitute.

When Sebastian first woos Moll, he does not think of what she might feel or think about that. He just ignores her feelings because he only seems to care about his situation with Mary. He knows that his father will certainly diagree with his marriage to Moll, and Mary is preferable without any doubt for Sir Alexander as he himself thinks that Moll is not a suitable girl to marry and she has a bad name for her behaviours in public. It is obvious that Sebastian is prejudiced against Moll, too. Even Mary thinks the same way which is seen in their speech when they talk about their plan:

Sebastian. [To Mary] This is the roaring wench must do us good. Mary. No poison, sir, but serves us for some use, Which is confirmed in her. (Act IV Sc.I, 147-149)

As Srivastava et al. (2017) suggest "patriarchy can be defeated if women recognize their own value and strength, establish a sisterhood of trust with other women”. However, it is understood that Mary is also prejudiced against Moll, which corroborates the public opinion and the contemptuous attitude toward Moll; and what is more, Mary Fitzallard seems to look down upon Moll, someone of the same gender as herself, just because Moll has become publicly notorious because of her 'so-called' uncommon behaviours. For example, Moll usually dresses like a man and sometimes wears the female and male outfits together at the same time which makes her look androgynous most of the time. Even Laxton and Trapdoor do not recognise her in man's clothing. But androgyny gives Moll freedom as she can walk and talk the way she likes, and she is able to fight when she wears a male outfit. She wants the tailor to make her clothes comfortable, too, as seen in this speech:

Tailor. You change the fashion; you say you'll have the great Dutch slop,

Mistress

Mary.

Moll. Why, sir, I say so still.

Tailor. Your breeches then will take up a yard more. Moll. Well, pray look it be put in then.

Tailor. It shall stand round and full, I warrant you, Moll. Pray make 'em easy enough. Tailor. I know my fault now: t'other was somewhat stiff between the legs;

I'll make these open enough, I warrant you. (Act II. Sc.II, 81 90)

According to Moll the comfortableness of an outfit is more important than how it looks. Therefore, she even prefers male clothes in order to feel as easy as possible, and it has become a habit of her to dress like a man. Furthermore, she is most commonly referred with the generic name "Jack" when she is in male attire. For instance, 
Sir Davy Dapper's son Jack calls Moll “Master Captain Jack” (Act V, Sc.I, 1).

It is understood that wearing both male and female outfits at the same time was becoming more popular among people in England in the first quarter of the $17^{\text {th }}$ century and this arose criticism against cross-dressing and hermaphroditism, i.e. combining elements of the dresses of both sexes. Anonymously published in 1620, Hic Mulier or The Man-Woman criticises the increasing inclination between women to wear man's clothing. The writer of this pamphlet claims that women who look like men by attire would behave like men, and that makes them neither man nor woman which is good for nothing (https://web.archive.org/web/20110519050 728/http://www.english.ucsb.edu/teaching/ resources/reading_lists/renaissance/hic_m ulier.asp). Haec-Vir or The WomanishMan was published in the same year as a response to Hic Mulier, focusing on mostly men in female clothing with a more tolerant approach to cross-dressing. The anonymous writer of the pamphlet argues that clothes should be worn to make people warm or comfortable, and there should not be any restrictions on clothing even if the wearer is a woman or a man unless it is excessive (https://johnwesleeellisetchison.wordpress. com/primary-documents/haec-vir-or-the-

womanish-man-1620/). Moll prefers wearing comfortable clothes, too; however, she almost always dresses up like a man which makes it harder for people to tell if she is a woman or not.

Apart from wearing fine clothes women are also supposed to like jewellery as Sir Alexander claims when he is leaving his valuables out thinking that Moll will steal them. He hangs up his ruff band with the diamond at it supposing that she will like it the best. However, Moll only comments on the gems and does not attempt to steal them. She does not pay attention to the beauty or attraction of them at all because she prefers comfortable and handy garments rather than heavy jewellery. It is clear that she does not pay attention to the outer look or what people think of her garments.

Since Moll is suspected to be a whore, Sir Alexander plans to prove this publicly in order to ruin her reputation and to prevent his son's marriage with her. But he does not really know whether she is a whore or not. Perhaps, he would have not thought about it at all if his son had not proposed to her. He acts in a defensive and destructive way at the same time taking the public opinion about Moll to a worse point. It is not even clear if the society is certainly sure that she is a whore. Larry Champion has noted that these social assumptions were arising either from chauvinistic sexual innuendo or from her refusal to accept the streotyped role indicated by a male-dominated society (1985). Moll is expected to marry someone if she wants to prove her dignity in the eyes of the society. However, she strongly refuses to succumb to that androcentrism.

Sir Alexander aims to slander Mary Fitzallard, too, just because he does not want his son to marry her. Although she is the daughter of Sir Guy Fitzallard and from a noble family, Sir Alexander says "What is she but a beggar's heir?"(Act I, Sc.II, 87). His assumptions cannot go far from being only a piece of gossip because she is already respected due to her father's status, but Moll, being defenseless, is at the center of calumny. The rumours about Moll being a street walker spread so quickly by means of Laxton because he believes that she is dissolute for she wears 
male clothes. He thinks that Moll dresses up like this in order to attract attention. Yet, even though he expects her to wear a shag ruff, a frieze jerkin, and a short sword, he does not recognize her at first sight when she meets him in male attire. Indeed, Laxton presumes that she is a hired whore and wants her to come into the coach as they can be spied, but this makes Moll furious. She then makes the following critical comment on him and the gallants in general:

Moll. To teach thy base thoughts manners! Thou' rt one of those That thinks each woman thy fond flexible whore: If she but cast a liberal eye upon thee,

Turn back her head, she's thine; or amongst company, By chance drink first to thee, then she's quite gone, There's no means to help her; nay, for a need, Wilt swear unto thy credulous fellow lechers

That thou' rt more in favour with a lady

At first sight than her monkey all her lifetime. (Act III, Sc.I, 72-80)

According to Moll, Laxton is one of those base men who suppose all women have the tendency to become a whore, and due to such an attitude towards them there are many women whose reputation have been ruined by slanderers or who have been compelled to prostitute themselves. She ends her lengthy speech saying that she herself is not a whore and will never be:

I scorn to prostitute myself to a man,

I that can prostitute a man to me! -
And so I greet thee. (Act III, Sc.I, 111-113)

After this conversation about men defaming and belittling women, Moll considers Laxton as the representative of all the slanderers, thus they fight which results in Moll's wounding Laxton. Jennifer Low (2003) argues that Moll resorts to her sword to teach Laxton a lesson and she does not attempt to prove her worthiness by fighting as she has already passed the point where community opinion affects her. It is true that Moll gives a lesson to him which might as well set an example for the others, and she fights only when a man looks down on a woman. She says it out loud several times in the play that she does not care about what the public opinion is: "Perhaps for my mad going some reprove me: I please myself and care not else who loves me." (Act V, Sc.II, 348-349), and "I pursue no pity - follow the law, and you can cuck ${ }^{3}$ me, spare not; hang up my viol by me, and I care not!” (Act V, Sc.II, 252-254). It is interesting that Moll uses the word 'mad' to define herself, but it might be because she wants to protest the people who call her 'mad' or she uses it on purpose to imply that she behaves like this deliberately although this makes her seem unnatural among society.

As Jennifer Low (2003) states, men use language as a means to control women, either directly through commands or indirectly through slander. Moll is the one who is slandered the most in the play. Sir Alexander refers to her as "a scurvy woman”, “a varlet”, “a naughty pack”, “a monster with two trinkets”, “a thief”, “a

\footnotetext{
3 Put on the cucking stool, i.e. an instrument of punishment that consists a chair in which offenders were ducked in water, a punishment not used any more.
} 
devi l rampant", and "monstrous impudence" from the beginning till the end of the play. Only after he perceives that Moll did not really intend to marry Sebastian, he apologizes and says "In troth, thou'rt a good wench; I'm sorry now” (Act V, Sc.II, 227). Apparently, he realizes his own mistake and the wrong opinion he had about her. But it is not clear if he changes his mind for he now thinks that Moll is a good woman just because she did not marry Sebastian or because he really understands Moll's real character. If a quick look is taken at his early speeches about Moll, it leaves a question mark in one's mind whether he really changes his mind about her or not:

Sir Alexander. Didst never, as thou hast walked about this town, Hear of a wench called Moll Mad, Merry Moll? Trapdoor. Moll Cutpurse, sir? Sir Alexander. The same; dost thou know her then? (Act I, Sc.II, 119122)

Sir Alexander. Methinks her very name should fright thee from her And never trouble me. Sebastian. Why is the name of Moll so fatal, sir?

Sir Alexander. Many one, sir, where suspect is entered, For seek all London from one end to t'other More whores of that name than of any ten other. (Act II, Sc.II, 150155)

If Sebastian really married Moll, it does not seem possible that Sir Alexander would think Moll is actually an honest and respectable woman rather than a whore and a thief. Because he abandons his slanders only after Moll says that she would never agree to marry Sebastian.
Indeed, Moll's opposition to marriage is seen both at the beginning and at the end of the play:

Moll. Sir, I am so poor to requite you, you must look for nothing but thanks of me: I have no humour to marry: I love to lie o' both sides $o^{\prime}$ th' bed myself; and again, o' th' other side, a wife, you know, ought to be obedient, but I fear me I am too headstrong to obey, therefore I'll ne'er go about it. I love you so well, sir, for your good will I'd be loath you should repent your bargain after, and therefore we'll ne'er come together at first. I have the head now of myself, and am man enough for a woman; marriage is but a chopping and changing, where a maiden loses one head, and has a worse i' th' place. (Act II, Sc.II, 35-45)

Moll. Who, I, my lord? I'll tell you when, i'faith. When you shall hear Gallants void from sergeants' fear, Honesty and truth unslandered, Woman manned but never pandered,

Cheaters booted but not coached, Vessels older ere they're broached; If my mind be then not varied, Next day following, I'll be married. (Act V, Sc.II, 216-224)

In the first speech, Moll states that she prefers to be free rather than live under the authority of a husband. The French author and philosopher Simone de Beauvoir (1953) states that after a girl is given to a man by her family she takes his name, gives her virginity, and the necessary loyalty, joins his religion, enters his universe, belongs to his family, participates in his class and environment, 
and eventually becomes a part of the man, which makes her lose some of the rights that single women have. It is clear that Moll does not want to lose the rights of a single woman, and the liberty to shape her own life, either. Furthermore, as Wiesner has noted, female freedom is determined and limited by male definitions, and the word 'free' is rarely used when referring to women (1986).

Both Moll Cutpurse and the Virgin Mary are, in fact, exceptional. But they are also seen as problematic, and they are always under suspicion regarding their physical wholeness. Virginity was considered to be the perfect condition for a female body and a mindset especially crucial to women in the medieval period (Schulenburg, 1986). But as it is stated in Medieval Virginities, "Virginity is a paradoxical condition, both perfect and monstrous, defined by both absence and presence" (Bernau, 2003). It is a perfect condition for both Mary Fitzallard and Virgin Mary, but it is monstrous for Moll Cutpurse for she stands against the ideals that are determined by others. It is noted in Women in Early Modern England that "Virginity was prized in young women, but after a woman passed the usual age of marriage, she was an object of suspicion” (Mendelson and Crawford, 1998). Thus, the longer Moll will stay single, the more suspicions and slanders will arise about her because she does not follow the idealized social rules for females such as getting married and childbearing.

These ideals were created by stereotyping women as maiden, wife, mother, or widow according to their marital stages in their lives. Others who did not fit in these stages were mostly accused of being a whore or a witch. Even today, women are described as Ms., Mrs., or Miss $^{4}$ according to their marital status although men are only defined as 'Mr.' which does not show any clue about whether they are married. The public concern on a woman does not end with her marital status. Wives were both idealized and criticized as mothers (Mendelson ve Crawford, 1998). If a woman did not have a child, she was accused of being barren like Anne and Elizabeth, but if she had one she could also be suspected about her chastity like Virgin Mary. Although marriage had its own disadvantages, it was better to get married and stay under the control of a husband rather than being accused of prostitution. The whores who represented uncontrolled sexuality were thought to have lost all womanly qualities, such as modesty, fidelity, and love, and that they were capable of all kinds of villainy (Mendelson ve Crawford, 1998). This is why Sir Alexander, who supposes that Moll is a whore, presumes that she is a thief, too.

As for the married women in the play, for instance, Mistress Gallipot, whom Laxton courts, deceives her husband to give money to Laxton by making up a story, but when he wants more money she gets anxious thinking that her husband will learn the truth. Because, as Eugene A. Hecker (1972) stated, the law of that time gave the husband the right to correct and chastise his wife, and he was to answer her misbehaviour. At first, the husbands were allowed to beat their wives, but then they were prohibited from using any violence to their wives. Despite the law which gives a husband authority over his wife,

\footnotetext{
${ }^{4}$ Mrs. is the formal title for a married woman Ms. is the title for a divorced woman or a woman whose marital status is unknown

Miss is the formal title for a woman who has never married
} 
Hippocrates Gallipot is far from using violence on his wife as he loves and protects her all the time, even though he has been cuckolded by his wife. He is also bad at seeing the reality about her and Laxton, and he is easily deceived by his wife and her wooer. Mr. Gallipot is a respected citizen with a good fame among the society while Laxton is only a man who courts women, drinks and fights. Therefore, Mr. Gallipot claims his right on his wife for he sees Laxton as a man with a lower status. When women get married, they change their status as well. Now Mrs. Gallipot is respected due to her husband, and Mr. Gallipot is worried about her status too together with his status. While a married woman could not make any contract on her own behalf, single women had the right to make a will or contract, hold land, and sue without the need of a guardian as Hecker (1972) stated. However, marriage was regarded as a proper stage in a woman's life. Wedlock was a way of changing social status for women, as well. Married women were more respected by the society, while the single ones like Moll were always expected to get married, and if they did not, they were highly suspected of being a whore. Why would a woman's virginity become a matter of public concern is uncertain, but it is obvious that the physical condition of women has always been an issue for society, which is seen in both The Mary Play and The Roaring Girl although they were written in different centuries.

\section{CONCLUSION}

To sum up, it can be said that Virgin Mary and Moll Cutpurse were at the center of public concern because of their femininity. The Mary Play, staged in the 15th century, and The Roaring Girl, staged in the 17th century, shed light on the attitude towards women in both Medieval and Early Modern England. Besides, the time gap between these two plays shows that the gender norms imposed on people did not change over the centuries. A woman's gender would still bring her certain limitations and expectations, and the accepted gender roles were still the same as they were ages ago.

Virgin Mary was compelled to get married when she was only fourteen as the law commanded. Moll Cutpurse was a matter of concern for the society as she did not marry although she was supposed to. Married women were criticised if they did not bear any children and they were called 'barren', because a woman's basic duty was considered childbearing only. Women's being labelled as potential sinners who need to be protected by men with wedlock as stated by St. Paul could also be pointed out as the reason why women have been considered dependant and subsequent to men by nature.

All in all, obviously, patriarchy is the main cause of female subordination, and of course an obstacle to the liberty of women. As a matter of fact, several views against male supremacy and the oppression of women have appeared throughout history, which may as well be called protofeminism. Protofeminist ideas, namely the pioneers of 'feminism', could be found in literary pieces like The Mary Play and The Roaring Girl. It is seen that there is a certain attitude in both plays contradictory to the patriarchal mindset of femininity, marriage and motherhood, which can be regarded as a pioneer of feminism that will emerge a few centuries later. For example, the attitudes of Virgin Mary's father Joachym and her husband 
Joseph are quite remarkable because their behaviors to their wives are on the contrary to what is expected from a husband in a patriarchal society. Indeed, they are far from subordinating their wives while they are under public concern, which could be regarded as an example of protofeminism. The personality of Moll

\section{REFERENCES}

Alkan, H. (2018). George Eliot'in "Middlemarch", Sarah Grand'in "Cennetlik Ikizler" ve George Moore'un "Esther Waters" Romanlarında Kadının Konumunun Psikanalitik Liberal Feminizm Yaklaşımıyla Incelenmesi. PhD Dissertation. Ankara: Ankara Üniversitesi Sosyal Bilimler Enstitüsü.

Beauvoir, S. de. (1953). The Second Sex. (Trans. H. M. Parshley). London: Lowe and Bryden Printers Ltd.

Bernau, A., Salih, S., \& Evans, R. (2003). Medieval Virginities. Cardiff: University of Wales Press.

Bottéro, J. (2001). Everyday Life in Ancient Mesopotamia. (Trans. Antonia Newill) Edinburgh: Edinburgh University Press.

Cereta, L. (1997). Collected Letters of a Renaissance Feminist. (Ed. and Trans. Diana Robin), Chicago: The University of Chicago Press.

Champion, L. S. (1985). Thomas Dekker and the Traditions of English Drama. New York: P. Lang. Feminism. Retrieved from https://www.britannica.com/topic/feminism

Haec Vir. Retrieved from https://johnwesleeellisetchison.wordpress.com/pri mary-documents/haec-vir-or-the-womanish-man1620/

Hecker, E. A. (1972). A Short History of Women's Rights. Westport, Connecticut: Greenwood Press.

Hic Mulier. Retrieved from https://web.archive.org/web/20110519050728/htt p://www.english.ucsb.edu/teaching/resources/read ing_lists/renaissance/hic_mulier.asp

İplikçi Özden, A. (2016). Mary Elizabeth Braddon'in "Lady Audley's Secret", Ellen Price'in "East Lynne” ve Anne Brontë'nin "The Tenant of Wildfell Hall" Romanlarındaki Kadin Imgesinin Fransız Feminizmi Bă̆lamında Incelenmesi. PhD Dissertation. Ankara: Ankara Üniversitesi Sosyal Bilimler Enstitüsü.

Johnston, A. F. (1999). The Mary Play. THE NTOWN PLAYS: A Modernization. Retrieved from
Cutpurse is also interesting because she acts in a manner opposite to what is expected from a young woman in the patriarchal Early Modern English society, and rejects the gender role which is imposed on her, which makes her a prominent protofeminist figure.

http://homes.chass.utoronto.ca/ ajohnsto/marypla y.html

Lerner. G. (1987). The Creation of Patriarchy. Oxford: Oxford University Press.

Low, J. A. (2003). Manhood and the Duel: Masculinity in Early Modern Drama and Culture. New York: Palgrave Macmillan.

McAfee, N. (2018). "Feminist Philosophy", The Stanford Encyclopedia of Philosophy (Fall 2018 Edition), Edward N. Zalta (ed.). Retreived from $<$ https:/plato.stanford.edu/archives/fall2018/entri es/feminist-philosophy/>

Mendelson, S. H., \& Crawford, P. M. (1998). Women in Early Modern England, 1550-1720. Oxford: Clarendon Press.

Meredith, P. (Ed.). (1997). The Mary Play: From The N. Town Manuscript. Exeter: University of Exeter Press.

Middleton, T., \& Dekker, T. (1987). The Roaring Girl. P. A. Mulholland (Ed.). Manchester: Manchester University Press.

Moll Frith. Retrieved from https://www.historicuk.com/HistoryUK/HistoryofEngland/Moll-Frith/

Nissinen, M. (1998). Homoeroticism in the Biblical World: A Historical Perspective. Minneapolis, Minn.: Fortress Press.

Plato. (1937). The Republic. (Trans. Paul Shorey). London: William Heinemann Ltd.

Rose, M. B. (1986). Women in the Middle Ages and the Renaissance: Literary and Historical Perspectives. $\quad$ Syracuse, N.Y.: Syracuse University Press.

Srivastava, K., Chaudhury, S., Bhat, P. S., \& Sahu1, S. (2017). Misogyny, Feminism, and Sexual Harassment. Industrial Psychiatry Journal, vol. 26, no. 2, 111-113.

St. Paul. (1973). 1 Timothy 2. Holy Bible, New International Version. Retrieved from https://www.biblegateway.com/passage/?search= $1 \% 20$ Timothy $+2 \&$ version $=$ NIV

Şanal, Y. (2018). Women in the Ideal Society: Utopia and The City of The Sun. Akademik Sosyal Araştırmalar Dergisi, Y11: 6, Sayı: 69, 376-386. 